\title{
EFICACITATEA PRODUSULUI NEEM01 ÎN COMBATEREA PĂDUCHILOR ÎN LIVEZI ȘI SPAŢII PROTEJATE
}

\author{
Tretiacova T., Todiraş V., Guşan A. \\ Institutul de Genetică, Fiziologie și Protecția Plantelor al MECC, Chișinău
}

\begin{abstract}
Considering the growing demand for organic production of food and registrationrelated problems, the number of pest management products that can be used in this sort of production is limited. In this study the efforts have been made to formulate the Neem oil emulsions which would be used as agrochemicals. Bioassays were performed on aphids (Myzodes persicae Sulz., Aphis gossypii Glow , Aphis pomi Deg.) in order to compare the insecticidal activity of the neem oil new preparative form NEEM-01 with that of the commercial biorational product Pelecol EO. The bioassays conducted on the aphids demonstrated that the NEEM-01 aplicated at the doze 8,0 1/ha was not effective as the commercial product Pelecol EO. But at the doze 10,0 1/ha new preparative form of neem oil has demonstrated a good biological effectiveness during 7 days after two treatments.
\end{abstract}

Key words: aphids, preparative form, treatment, effectiveness.

\section{Introducere}

Agricultura joacă un rol important în economia Republicii Moldova. Organismele dăunătoare răspîndite pe teritoriul Republicii Moldova, anual, în funcție de condițiile climatice, pot provoca pagube semnificative culturilor agricole, estimate la cca $25-30 \%$ din recolta preconizată. Actualmente, protecţia fitosanitară a culturilor agricole contra 
organismelor dăunătoare se efectuează prioritar prin utilizarea produselor chimice, datorită eficienţei sporite şi rapide a acestora. Principalele dezavantaje ale metodei chimice de combatere a organismelor dăunătoare sunt poluarea mediului ambiant şi dezvoltarea rezisţentei dăunătorilor la pesticide [1]. Impactul organismelor dăunătoare poate fi diminuat şi menţinut în limita pragului economic de dăunare, în condițiile respectării sistemului integrat de protecţie a plantelor, axat pe elemente tehnologice, economice, ecologice, inclusiv și utilizarea raţională a produselor de uz fitosanitar, pentru menţinerea echilibrului biologic. Agricultura convențională folosește pesticide pentru a proteja plantele, în agricultura ecologică, acestea sunt puternic restricționate. În ambele tipuri de agricultură, în Uniunea Europeană în prezent se iau măsuri pentru obținerea de produse mai sigure pentru consumatori.

Agricultura ecologică serveşte ca un model de agricultură care protejează mediul şi conservează natura. Având în vedere cererea tot mai mare de producție ecologică de alimente și problemele legate de înregistrare a acestora, numărul de produse de combatere a dăunătorilor care pot fi utilizate în acest tip de producție este limitat [2]. Elaborarea unui sistem ecologic de combatere a bolilor și dăunătorilor necesită elaborarea și implementarea preparatelor ecologic inofensive. În ultimii ani se acordă din ce în ce mai multă atenție utilizării compușilor naturali (cum ar fi uleiurile esențiale) ca opțiune promițătoare de înlocuire a produselor agrochimice în combaterea dăunătorilor agricoli. Aceste substanțe odorifere sunt extrase din diferite plante aromatice, care sunt surse bogate de metaboliți secundari biologic activi, cum ar fi alcaloizi, fenolici și terpenoizi. Mecanismele lor de acțiune pot varia, mai ales atunci când efectul se datorează unei combinaţii de compuși [1].

Uleiul de Neem este extras din arborele de neem, Azadirachta indica Juss., membru al familiei Meliaceae care provine din subcontinentul Indian și este acum apreciat la nivel mondial ca o sursă importantă de fitochimicale pentru utilizare în sănătatea umană și combaterea dăunătorilor. Uleiul de Neem conține cel puțin 100 de substanțe biologic active. Dintre aceștia, constituenții majori sunt triterpenele cunoscute sub numele de limonoide, cel mai important fiind azadirachtina, care pare să provoace $90 \%$ din efectul asupra majorităţii dăunătorilor [1,5]. În afară de azadirahtina, se mai enumeră componente ca: meliantriol, nimbin, nimbidin, nimbinin, nimbolide, acizi graşi (oleic, stearic și palmitic) și salannin; acid oleic si acid linoleic, fiind folosite ca insecticide, provocând asfixierea insectelor și a oualor acestora.

Uleiul din NEEM este considerat un insecticid de contact, prezentând activitate sistemică și translaminară [1]. Pesticidele pe baza uleiului de Neem joacă un rol esențial în gestionarea dăunătorilor și sunt utilizate pe scară largă în agricultura multor țări.

Scopul cercetărilor: Evaluarea eficacităţii biologice a formei preparative noi a produsului biorațional NEEM-01 în combaterea bolilor și dăunătorilor la culturile din câmp și spaţiu protejat.

\section{Material şi metode}

Investigaţiile în cadrul încercărilor formei preparative noi NEEM-01 în calitate de insecicid s-au efectuat în sera experimentală (castraveți) și în câmp deschis (trandafir, cireș, măr) a IPPAE al MECC în perioda de vegetaţie a anului 2020. Condiţiile meteorologice în 2020 în zona centrală a Moldovei, au fost favorabile pentru dezvoltarea şi răspândirea dăunătorilor (păduchiloe) la culturile de câmp și seră .

Uleiul de Neem este un pesticid natural și are proprietăți insecticide [4]. Prin urmare, în acest studiu s-au făcut eforturi pentru a formula emulsiile uleiului care ar fi utilizate ca produse agrochimice. Forma preparativă a produsului NEEM-01 este o soluţie uleioasă ce 
prezintă microemulsie. NEEM-01 este produs bioraţional, substanţa activă prezintă azadirachtina + adjuvant + surfactant (admis pentru agricultura ecologică).

Testările pe plantele de castraveți în condiţii de seră s-au efectuat la densitatea numerică a păduchilor nu mai mică de respectiv: 30 de exemplare adulte şi 140 de larve formarea coloniilor stabile. Schema experienţei a inclus 4 variante: Forma preparativă testată NEEM-01 - în 2 doze, etalon şi martor. Ca etalon a servit preparatul bioraţional Pelecol EO, utilizat în producere pentru combaterea acarienilor, musculiței albe de seră şi a păduchilor. Fiecare variantă a avut 4 repetiţii. Toate variantele şi repetiţiile au fost amplasate în aceeaşi seră, cu respectarea zonei de protecţie între variante. Observările fenologice şi sondajele de evidenţă s-au efectuat înainte de tratament și după 24 ore, la a 3-a și a 7-a zi după tratament, conform recomandărilor metodice [6]. Eficienţa biologică a tratamentelor în combaterea păduchilor a fost calculată după formula lui Henderson, C.F. and E. W. Tilton [3]. Prelucrarea statistică a datelor s-a făcut după Dospehov [7].

\section{Rezultate şi discuţii}

Afidele sau păduchii plantelor (Myzodes persicae Sulz., Aphis gossypii Glow , Aphis pomi Deg.) sunt micile insecte verzi care atacă florile, legumele sau livada fiind printre cei mai periculoși dăunători care pot distruge într-un timp record culturile.

Afidele pot avea diverse culori, cele mai des întâlnite fiind: verde, roșu sau brun. Lungimea corpului este de circa $1,5 \mathrm{~mm}$, în funcție de specie, iar larvele lor sunt mai mici și se aseamănă cu adulții.

Afidele trăiesc în colonii pe spatele frunzelor, pe vârfurile lăstarilor iar înlăturarea manuală a acestora este de-a dreptul imposibilă. Mai ales în lunile mai-iunie-iulie afidele își fac prezența în număr impresionant de mare și atacă plantele cărora le sug seva ceeea ce împiedică dezvoltarea acestora sau în cazul celor mai tinere pot să le distrugă efectiv. Păduchii formează colonii, se hrănesc prin sugerea sevei plantelor. Datorită acestui fapt, frunzele se deformează şi se răsucesc, formând pseudocecidii. Plantele atacate suferă şi se debilitează, ducând la scăderea producţiei.

Primăvara, cercetările, privind evaluarea eficacității formei preparative noi a produsului NEEM 01, au fost inițiate la prima aparițe a dăunătorilor (păduchii frunzelor de măr, cireș, trandafir) în natură. Tratamentele s-au efectuat la pomii de cireș, măr și plante de trandafir, doza produsului NEEM-01 fiind egală cu 10,0 1/ha. La trandafir tratamentul s-a aplicat în data de 11.05.20, eficacitatea produsului la a doua zi după tratare a constituit 78,57$84,79 \%$. La cireș tratamentul s-a efectuat în data de 14.05.20; la 24 de ore după tratare eficiența produsului testat era foarte scăzută, în medie - 26,4\%. La măr (18.05.20) ), la fel după 24 ore de la tratare eficacitatea biologică era scăzută și a variat de la 29,4 până la 61,9\%, în medie fiind egală cu 43,4\%. Tratamente la măr s-au aplicat și în luna iunie (16.06.20). Eficacitatea biologică a produsului NEEM-01 în combaterea păduchilor la măr a constituit $97,05-98,2 \%$, peste 48 ore $-81,63 \%$, la a 3-a zi după tratament eficacitatea s-a redus până la $60,59 \%$.

În luna iulie cercetările privind evaluarea eficacității produsului NEEM-01 în combaterea păduchilor au fost efectuate în sera experimentală a IGFPP la cultura de castraveți. Tratamentele au fost efectuate la apariția coloniilor stabile de păduchi. Datele experimentale, privind efiacitatea biologică a produsului NEEM-01 în combaterea păduchilor la castraveți, sunt prezentate în tabel (tab.1). 
Tabelul 1. Efecacitatea biologică a produsului NEEM-01 în combaterea păduchilor la castraveţi, sera experimentală a IGFPP al MECC. Chișinău, 13.07.20

\begin{tabular}{|c|c|c|c|c|c|c|c|c|}
\hline \multirow[t]{3}{*}{ Varianta } & \multirow{3}{*}{ 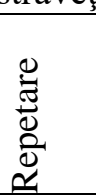 } & \multicolumn{4}{|c|}{$\begin{array}{c}\text { Densitatea numerică medie a } \\
\text { păduchilor la o frunză }\end{array}$} & \multirow{2}{*}{\multicolumn{3}{|c|}{ Eficacirtatea biologică \% }} \\
\hline & & \multirow{2}{*}{$\begin{array}{l}\text { Pănă la } \\
\text { tratare }\end{array}$} & \multicolumn{3}{|c|}{ In zilele de evidenţă } & & & \\
\hline & & & 24 ore & 3 zile & 7 zile & 24 ore & 3 zile & 7 zile \\
\hline $\begin{array}{l}\text { NEEM-O1- } \\
8,01 / \mathrm{ha}\end{array}$ & med. & 180,00 & 46,00 & 84,00 & 157,00 & 77.67 & 67.64 & 58.89 \\
\hline $\begin{array}{l}\text { NEEM-O1 } \\
-10,0 \text { l/ha } \\
\end{array}$ & med. & 176,00 & 15,00 & 47,00 & 80,00 & 92.39 & 81.46 & 78.58 \\
\hline $\begin{array}{l}\text { St (Pelecol)- } \\
10,0 \text { 1/ha }\end{array}$ & med. & 188,00 & 15,00 & 29,00 & 49,00 & 93.02 & 89.31 & 87.73 \\
\hline Martor & med. & 181.0 & 207.0 & 261.0 & 384.0 & 0.0 & 0.0 & 0.0 \\
\hline \multicolumn{2}{|l|}{$\mathrm{DEM}_{05}$} & 5.5 & 4.14 & 4.97 & 7.8 & - & - & - \\
\hline
\end{tabular}

Analizând datele prezentate în tabelul 1, se poate observa că produsul NEEM-01 în doză 8,0 1/ha n-a fost suficient de efectiv în combaterea păduchilor la castraveți. În același timp, produsul în doză de 10,0 1/ha a demonstrat o eficacitate insecticidică înaltă pe durata a 3 zile după tratament. Astfel, peste 24 ore după tratament eficacitatea biologică a produsului la varianta NEEM-01 în doza 8,0 1/ha a fost egală cu 77,67 \%, la NEEM-01 în doza de 10,0 1/ha - 92,39\%, aceasta fiind la nivel cu etalon (Pelecol EO). La a 3-a zi după tratament eficacitatea biologica a scazut ușor și a constituit la varianta NEEM-01 în doza 8,0 1/ha - 67,64\%, la varianta NEEM-01 în doza 10,0 1/ha - 81,46\%, aceasta fiind la nivelul mai jos decât la etalon $(89,3 \%)$. Eficacitatea biologică a produsului după 7 zile a fost: NEEM-01 în doză 8,0 1/ha 58.89\%; NEEM-01 în doză 10,0 1/ha - 78.58\%; Etalon (Pelecol EO) - 87,73\%. E de menționat că înmulțirea afidelor în perioada evidențelor după primul tratament, era la un nivel ridicat, păduchii refuzând sa manânce din frunzele tratate, rămânând vii. Reieșind din faptul că produsul NEEM-01 are în preponderență acţiune de contact, pentru asigurarea eficacităţii mai înalte în combaterea păduchilor la castraveţi în seră pe data de $21.07 .20 \mathrm{~s}-\mathrm{a}$ efectuat al doilea tratament în combaterea păduchilor la castraveți (tabelul 2).

La evidența după 24 de ore de la tratament, la varianta cu produsul NEEM-01 în doza de 8,0 1/ha a s-a înregistrat o eficiență de 72,35\%, la NEEM-01 10,0 1/ha - 90,11\%, iar etalonul fiind egală cu 94,5\%. În a 3-a zi de la tratament eficienta biologică a produsului a uşor a scazut și a constituit la varianta NEEM-01 8,0 1/ha - 66,79\%, NEEM-01 10,0 1/ha $87,09 \%$, Etalon (Pelecol EO) - 91,38 \%. În literatura de specialitate este menționat că Azadirahtina ca substanța activă a produsului NEEM-01 reduce alimentarea insectelor și acționează ca un agent de respingere sau repelent [1]. La a 7-a zi după al doilea tratament produsul NEEM-01 în doza 10,0 1/ha a manifestat activitatea translaminară și de repelent împotriva păduchilor. S-a observat că după două tratamente afidele nu populează plantele din varianta NEEM-01 în doza 10,0 1/ha timp de 10-14. Eficacitatea produsului la a 7-ea zi la variantă NEEM-01 în doza 10,0 1/ha a constituit 91,38\%, fiind mai înalta decât după prima zi de tratament. La varianta NEEM-01 în doza 8,0 1/ha eficacitatea biologică la a 7-a zi menținându-se la 61,38\%, iar etalonul fiind de 89,80\% (tabelul 2). Datele sunt prealabile, cercetările este necesar de a continua privind precizarea duratei de acțiune a produsului, concentrației optimale și proprietăților de repelent. 
Tabelul 2. Efecacitatea biologică a produsului NEEM-01 în combaterea păduchilor la castraveţi, sera experimentală a IGFPP al MECC. Chișinău, 21.07.20

\begin{tabular}{|c|c|c|c|c|c|c|c|c|}
\hline \multirow[t]{3}{*}{ Varianta } & \multirow{3}{*}{ 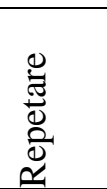 } & \multicolumn{4}{|c|}{$\begin{array}{l}\text { Densitatea numerică medie a păduchilor } \\
\text { la o frunză }\end{array}$} & \multirow{2}{*}{\multicolumn{3}{|c|}{ Eficacirtatea biologică \% }} \\
\hline & & \multirow{2}{*}{$\begin{array}{c}\text { Pănă la } \\
\text { tratare }\end{array}$} & \multicolumn{3}{|c|}{ În zilele de evidenţă } & & & \\
\hline & & & 24 ore & 3 zile & 7 zile & 24 ore & 3 zile & 7 zile \\
\hline $\begin{array}{l}\text { NEEM O1 } \\
-8,01 / \mathrm{ha}\end{array}$ & med. & 257,00 & 77,00 & 102,00 & 151,00 & 72.35 & 66.79 & 61.31 \\
\hline $\begin{array}{l}\text { NEEM O1 } \\
-10,0 \text { 1/ha }\end{array}$ & med. & 84,00 & 9,00 & 13,00 & 4,50 & 90.11 & 87.09 & 91.38 \\
\hline $\begin{array}{l}\text { Standard } \\
(\text { Pelecol) } \\
10,0 \text { 1/ha }\end{array}$ & med. & 58,00 & 3.50 & 6,00 & 9,00 & 94.45 & 91.38 & 89.80 \\
\hline Martor & med. & 384.0 & 416.0 & 460.0 & 583.0 & 0 & 0 & 0 \\
\hline \multicolumn{2}{|c|}{$\mathrm{DEM}_{05}$} & 6.52 & 4.58 & 4.97 & 5.1 & - & - & - \\
\hline
\end{tabular}

\section{Concluzii}

Forma preparativă nouă a produsului bioraţional NEEM-01 în baza uleiului din semințe de NEEM (Azadirahta indica) corespunde cerinţelor agriculturii ecologice.

Avantajul aplicării acestui produs este că oferă potențialul de a controla dăunătorii agricoli, fără efecte grave asupra mediului, a organismelor nevizate și a sănătăţii animale și umane. S-a observat că produsul NEEM-01 nu a influențat negativ asupra fazelor larvare a astfel de entomofag ca Aphidoletes aphidimiza.

Produsul NEEM-01 în doza 10,0 1/ha, având acțiune translaminară, a manifestat eficacitatea biologică înaltă timp de 7 zile.

Produsul NEEM-01 după două tratamente a manifestat proprietăţile de repelent , afidele n-au mai populat plantele tratate timp de 10-14 zile. Datele prezentate sunt inițiale, cercetările urmând a fi continuate.

\section{Bibliografie}

1. Campos, E.V.R.; de Oliveira, J.L.; Pascoli, M., et al. Neem Oil and Crop Protection: From Now to the Future. In: J. Front Plant Sci. 2016; 7: 1494. Published online 2016 Oct 13. https:// doi: 10.3389/fpls.2016.01494

2. Gonzalez-Coloma, A.; Reina, M.; Diaz, C.E. et al. Natural Product-Based Biopesticides for Insect Control. In: Comprehensive Natural Products II. 2010, vol. 3, pp. 237-268

3. Henderson, C.F. and E. W. Tilton, 1955. Tests with acaricides against the brow wheat mite, J. Econ. Entomol. 48:157-161.

4. Shrinivas C. Kothekar; Shamim A. Momin. Formulating Neem Oil Emulsion as Potent Agrochemicals Using a Binary Emulsifier System. In: Journal of Dispersion Science and Technology. 2008, 29(6):919-929.

5. Usharani KV, Dhananjay Naik and Manjunatha RL. Neem as an organic plant protectant in agriculture. Journal of Pharmacognosy and Phytochemistry 2019; 8(3): 4176-4184. 